\title{
The Charming Threat Against the Groundwater Resources: Tamarix Trees Utilized for Landscaping
}

\author{
Muhammed Ernur Akıner ${ }^{*}$, Časlav Lačnjevac ${ }^{2}$ \\ 1* Akdeniz University, Vocational School of Technical Sciences, Department of Environmental Protection Technology, Antalya, Turkey, (ORCID: 0000-0002-5192- \\ 2473), ernurakiner@akdeniz.edu.tr \\ ${ }^{2}$ University of Belgrade, Faculty of Agriculture, Belgrade, Department of Chemistry and Biochemistry, Serbia, (ORCID: 0000-0003-0650-8625), \\ caslav.lacnjevac@gmail.com
}

(First received 20 June 2021 and in final form 22 August 2021)

(DOI: $10.31590 /$ ejosat.954953)

ATIF/REFERENCE: Akıner, M. E. \& Lačnjevac, Č. (2021). The Charming Threat Against the Groundwater Resources: Tamarix Trees Utilized for Landscaping. European Journal of Science and Technology, (27), 210-220.

\begin{abstract}
Datça peninsula has a limited water budget due to its geographical structure. Although many studies have been carried out to protect water resources, no study has been conducted on some specific plant species' excessive water consumption for the Datça region. The study identifies and evaluates the negative impacts of Tamarix spp (Tamaracaceae) across the coastal landscapes of Datça. As an invasive alien species, initially used as a short-term solution to flooding and increasing soil nutrients, Tamarix spp has more adversities than the anticipations held during its introduction. Tamarix plant has compromised several ecosystems hence rendering it an extremely repulsive plant that requires termination. The study utilized literature to garner relevant information regarding the topic and its associates with the ecological systems and the overall environment. The study points out that Tamarix is responsible for water scarcity, species displacement, fire hazards, inhospitality of riparian areas, and altered soil systems. Further, the study argues that control measures have been adopted to terminate and reduce the risks of Tamarix. Overall, this study underlines the requirement of lowering the depletion rate of the underground freshwater source by preventing the excessive water consumption of future threat, Tamarix parviflora trees, which start from the coastal regions and spread to the inner areas of Datça.
\end{abstract}

Keywords: Datça, Negative implications, Species displacement, Tamarix parviflora, Water scarcity.

\section{Yeraltı Suyu Kaynaklarına Yönelik Tehdit: Peyzaj Amaçlı Kullanılan Ilgın A ğaçları}

$\ddot{\mathbf{O} z}$

Datça yarımadası coğrafi yapısı nedeniyle sınırlı bir su bütçesine sahiptir. Su kaynaklarının korunmasına yönelik pek çok çalışma yapılmasına rağmen, Datça bölgesi için bazı spesifik bitki türlerinin aşırı su tüketimi ile ilgili herhangi bir çalışma bulunmamaktadır. Bu çalışma, Ilgın Ağacı türlerinin (Tamaracaceae) Datça kıyı peyzajı üzerindeki olumsuz etkilerini belirlemekte ve değerlendirmektedir. Başlangıçta taşkınlara karşı ve topraktaki besin maddelerinin arttırılması amacıyla kısa vadeli bir çözüm olarak Tamarix spp kullanılmıştır. İstilacı bir yabancı tür olan Ilgın Ağacı, peyzaj için yaygın olarak bilinen faydalarının yanı sıra masum görüntüsünün altında yeraltı suları için tehdittir. Ilgın Ağacı zamanla ekosistemi tehlikeye atmış, bu durum da onu süreç içerisinde bertaraf edilmesi gereken bir tür haline getirmiştir. Bu makalede, ekolojik sistemler ve genel çevre ile ilgili literatür araştırması sonucunda elde edilen bulgular, Ilgın Ağacının Akdeniz Bölgesi’nin cennet köşelerinden biri olan Datça bölgesine verdiği zararlara işaret etmektedir. Araştırmada ulaşılan sonuçlar göstermektedir ki Ilgın Ağacı, Datça bölgesinde su kıtlığından, türlerin yer değiştirmesine, yangın tehlikesinden, nehir kıyısındaki alanlarda diğer bitki türlerinin yerlerinin alınarak istila edilmesine ve değişen toprak sistemlerine kadar pek çok olumsuzluğun sorumlusudur. Ayrıca bu makale Ilgın Ağacının risklerini sona erdirmek ve azaltmak için gerekli önerileri sunarken, acil kontrol önlemlerinin alınması gerektiğini de savunmaktadır. Genel olarak, bu çalışma, gelecekteki aşırı su tüketiminin önlenerek yeraltı tatlı su kaynağının tükenme oranının düşürülmesi için kıyı bölgelerinden başlayıp Datça'nın iç bölgelerine yayılan Tamarix parviflora türü Ilgın Ağaçlarının popülasyonunun azaltılması gerektiğinin de altını çizmektedir.

Anahtar Kelimeler: Datça, Ilgın Ağacı, İstilacı tür, Su kıtlığı, Tamarix parviflora.

\footnotetext{
* Corresponding Author: ernurakiner@akdeniz.edu.tr
} 


\section{Introduction}

Tamarix tree, commonly termed as salt cedar (Tamarix parviflora mainly planted in Datça, Tamarix ramosisina, Tamarix chinensis, and Tamarix aphylla), is an invasive plant that has been overly considered for landscaping purposes. It belongs to the Tamarisk Family (Tamaracaceae). The plant is a deciduous and decorative shrub majorly admired for its feathery foliage and tiny blossoms. Simultaneously, the plant is referred to as an ancient cultivar and best praised for its resilience in impeccable habitats (Sher et al., 2018). Interestingly, salt cedar is a pretty flowering shrub with a magnificent addition to the landscape (Xia et al., 2021). More so, the plant is noted to have a framed resistance on saline soils and habitats, a reason that makes it efficient for a sea garden. Notably, Tamarix spp traces its habitats more in the Southwest US and northern Mexico. In many countries, particularly in the UK, the plant's application range as a favorite coastal decoration.

However, several questions arise regarding the recreational implementation of the Tamarix tree. In coastal areas, especially beach areas, some municipalities are planting Tamarix trees for landscape purposes. They aim to create a green cover that does not require irrigation and maintenance on the coastline by planting these trees that can consume salty seawater. However, what happens if it negatively affects the environment, such as water scarcity, in a more extended period? Could the Tamarix plant harm the ground in the future? Is there a possibility of spontaneous expansion from the coast towards the interior? Does this situation cause depletion of clean water resources, decreased plant diversity, and natural habitat change? Is it wise to use Tamarix tree for landscaping on beaches, or is it a short-term solution but an environmental problem in the long term?

Over the years, the Tamarix tree has been considered an invasive alien plant that does more harm than good in its application along coastal beaches. Initially, the plant was introduced across the US coastlines for recreation purposes. The plant has been linked with efficient landscaping by creating a green cover efficient enough not to require irrigation. However, the invasive impact tied to the Tamarix tree, also called salt cedar, alters the soil system and changes the community and ecosystem processes. Its invasive nature's adverse implications have caused detrimental environmental outcomes ranging from the displacement of native vegetation and animals and lowering the water table. Wildlife is affected by the Tamarix due to a lack of protein found in the plant rendering it unfit for consumption. Many native birds also find the plant undesirable. More so, the Tamarix spp is linked to altered soil salinity and increased fire frequency (Los Huertos, 2020). Ideally, salt cedar application as a short-term solution to stand stabilization has induced a long-term era of premature loss across the coastal beaches.

Thus, nowadays, coastal dunes stand as some of the most threatened ecosystems due to the invasion of alien plant species (Gallego-Fernández et al., 2021). The sand's short-term stabilization was almost always reached at the expense of longterm ecological sustainability (Feagin et al., 2019).

\subsection{Problem Statement}

The introduction and continued use of Tamarix tree species in various parts of the world have become more problematic than anticipated. As a once introduced species to counter flooding and drain swamps, the plant has been quite effective. However, it was not until decades later that its extremities in the environment were detected.

Adverse environmental effects, primarily on coastal areas where the plant is used for landscaping, are pretty rampant. Mainly, Tamarix spp is linked to massive damage to the ecosystems where it habits. More importantly, the problem of water scarcity and increased wild and forest fires is at its peak. Besides that, the displacement of native plants from their natural habitats and a consequential impact on wild animals is also a trending factor. Furthermore, the salt excretion from salt cedar inhibits the growth and development of other plants. While the plant was considered a short-term solution to flooding problems, it has seemingly turned out to impose long-term adversities on the environment.

\subsection{The Motivation}

Research Objectives are to establish the adverse implications of Tamarix spp plant to the environment, review various literature regarding the negative impact of Tamarix tree on the ground, and develop a foundation for effectively controlling Tamarix tree impacts.

Another question that arises is if the Tamarix tree is dismantled to decrease the Tamarix tree's negative impact, what could be an alternative tree name(s) that can replace Tamarix, compatible with the Mediterranean climate, grow in a short time, tolerant to the salty water like Tamarix, but does not harm the habitat like Tamarix?

\subsection{Background Information: History and Features of Tamarix spp}

As a lovely and flowering shrub, the history and original habitat for the Tamarix tree trace back to Eurasia. The Tamarix is known to us from the Bible; when Abraham reached Beersheba, the first thing he did was plant a tamarisk tree to sat underneath since it is a very rapid growing weed (King James Bible, 2020).

A large portion of the Tamarix tree-related researches has been conducted in the United States of America (US). Notably, the plant was first introduced in the US in the 1800s from Europe, Asia, and North Africa (El Waer et al., 2018). More importantly, the plant was explicitly introduced in the US as an ornamental plant for landscaping. Over the years, the Tamarix species has spread and occupied more than 800,000 ha in a riparian habitat in the US's southwestern region. Among the widely considered and utilized Tamarix species include Tamarix ramosissima, Tamarix chinensis, and Tamarix aphylla.

Tamarix spp is an aggressive and habitat generalist with a spreading characteristic of either a tree or a shrub. El Waer et al. (2018) explain that the plant exhibits many offspring alongside high longevity. Besides that, salt cedar has a height range of between $1.5-8$ meters tall (Powell, 2005). Notably, Tamarix spp has a high existence length of close to 100 years and can produce an average of 500,000 seeds annually (Sher et al., 2018).

Tamarix (Saltcedar) tree is very prolific, and it also conditions the soil so that other plants can't grow around it after a few years. Therefore it takes all of the water, nutrients, space, and sunlight from the other plants. Leaves are shed every winter, and they fall to the ground. They condition the soil then nothing else can grow around them because it is too salty. It is making its bed just for itself and its offspring to grow display. In a lot of different ways, it knows how to survive. 
Further, the plant has distinguished petals and sepals grouped in fours and fives and a higher capability to be established based on a large seed output. Furthermore, Tamarix spp is highly known for its high-water consumption rate, with a record of more than 750 liters per day (Owens \& Moore, 2007).

According to research, the plant is majorly characterized by its high drought resistance capabilities (El Waer et al., 2018). Further, more studies illustrate that salt cedar has a high evapotranspiration rate that makes it easily adaptable to water availability (El Waer et al., 2018). Similarly, the plant manifests a facultative phreatophyte alongside an adjustable feature that allows it to rely on both surface and groundwater (Xia et al., 2021). In this light, the plant has been linked with displacing and replacing native plants like cottonwoods, willows, and other riparian vegetation from their natural habitats. Notably, after introducing the Tamaris spp, species in the US and other world parts, its severe implications were later noted. Upon its introduction in the US, particularly around the 1800s, the plant's landscaping uses were preceded by its threats to the environment. Around the $1920 \mathrm{~s}$, the plant was identified as a potential threat to vegetation and other ecosystems (Chew, 2009).

\subsection{Literature Review}

The ecological threats posed by Tamarix spp have cost a gross loss environmentally and continues to increase the vulnerability of all ecosystems, especially regarding the inhospitality of the riparian areas. According to a study conducted by Marlin et al. (2017), the Tamarix tree is an invasive species that extends beyond its native range. The fact that the plant is saline tolerant and excretes salt through their leaves glands exposes the surrounding plants to growth difficulties (Marlin et al., 2017; El Waer et al., 2018). In this light, the plant is highly linked with making the surrounding area inhospitable for other species. Similarly, El Waer et al. (2018) argue that the plant's specific characteristics, like being deeply rooted, allow it to reach deeper water tables than other plants could.

On another note, Setshedi \& Newete (2020) highlight a decline in the diversity of plants and animals around these riparian areas, an instance that raises more concern for Tamarix species. More so, Raynor et al. (2017) explore that riparian areas have been primarily affected by invasive and non-native plants. Further, the researchers have established that inhospitality across riparian habitats is a growing global problem majorly common in Tamarix-dominated sites (Raynor et al., 2017; Uhey et al., 2020). Furthermore, non-native plants like Tamarix spp have induced ecological changes across these habitats, thus altering the natural homes for various species. Notably, another research by Liu et al. (2017) indicates that Tamarix species cause an increase in soil salinity by raising the salt content.

Secondly, research illustrates how alien species, for example, Tamarix spp, have impacted the longevity and adaptability of coastal dune communities (Šilc et al., 2019). The dominance of the Tamarix plant in the coastal vegetation threatens the survival of the dunes and the associated ecosystems. Notably, in their research, Stešević et al. (2017) explain that continued disturbances of alien species continuously threaten dunes' prevalence as solid ecosystems. Further, the study indicates that alien species pose both natural and anthropogenic disturbances that compromise dunes' thriving and survival rates in their invaded habitats (Stešević et al., 2017). Lack of diversity among dune ecosystems is also a significant impact from Tamarix spp
(Šilc et al., 2019). In this light, Šilc et al. (2019) explain the conflicts between nature conservationists and landscape planners if the Tamarix tree is detrimental.

Research highlights that salt cedar has highly impacted wildlife, especially since it is not fit for their consumption (Kueffer, 2017). The leaves and stems of salt cedar secrete high salt content to the ground, raising the surrounding soils' salinity (El Waer et al., 2018; Erfanifard \& Khosravi, 2019; Liu et al., 2017)). Less growth of native plants reduces the food available for wild animals. On another note, Horoshevsky (2020) confirms that the high salt content of Tamarix spp inhibits the protein content. Furthermore, the research highlights that the lack of protein found in the plant renders it unfit for consumption, hence predominantly affecting the wildlife (Horoshevsky, 2020).

At the same time, another study illustrates that native birds similarly find the plant undesirable and unfit for consumption (Raynor et al., 2017). More so, a study by Richards et al. (2021) explains that Tamarix spp has resulted in poor habitat for most wildlife. Richards et al. (2021) also spotlight that Tamarix species have reduced the cobble bars and back channels as essential and crucial elements for healthy fish habitat. Therefore, other studies establish that the plant is linked with changes in the natural habitats; hence wildlife survival in their invaded habitats is compromised (El Waer et al., 2018).

Besides that, Richards et al. (2021) confirm that Tamarix spp contributes to water wastage and long-term shortage in interior and semiarid regions. In their study, Chen et al. (2019) point out that Tamarix has a high evapotranspiration rate that accounts for $60.2 \%$ of the average evapotranspiration rate. Statistics from the same research highlights that the evapotranspiration rate ranged from 514.2 to $573.8 \mathrm{~mm}$ annually (Chen et al., 2019). Consequently, the depletion of fresh and clean water sources is observed by El Waer et al. (2018). Another study illustrates that the Tamarix species consume more than 4 -acre feet $(4933 \mathrm{~m} 3)$ of groundwater annually. In their research, Richards et al. (2021) identify that tamarisk's tendency to grow in high densities increases daily water uptake compared to the riparian vegetation. The same study explains that tamarisk plants' deep roots allow them to access deeply positioned groundwater alongside other areas far from riverbanks (Richards et al., 2021).

Lastly, research indicates that tamarisk is linked to increasing wild hazards such as fires (Richards et al., 2021). On the same note, the study suggests that Tamarix is a fire-resistant plant with leaves, roots, and stems adaptable to fire niches (Richards et al., 2021). Simultaneously, a study by El Waer et al. (2018) also illuminates that Tamarix species' roots are well adapted to sprout and develop in burning or burnt areas. Further, due to the dense thickets and woods in the Tamarix habitats, large amounts of dead and live dry woody materials are common, which add to fuel load hence increasing the ecosystem's vulnerability in such surroundings (Richards et al., 2021). Therefore, some researchers have focused on how attempts to control Tamarix are faring (González et al., 2017). Researches by Sher et al. (2018) and Mc Kay et al. (2018) illuminate that various control measures such as biological control have been utilized to reduce Tamarix impact. McAlpine et al. (2021) also suggest that succession trends are an efficient biological control method that manipulates the survival of Tamarix. El Waer et al. (2018) and Richards et al. (2021) also confirm the research by Sher et al. (2018) that mechanical control methods like cutting, chemical treatment, and root plowing are efficient ways to reduce resprouts of Tamarix species. Similarly, 
research by Woutersen et al. (2018) highlights that alternative plants may be considered in place of Tamarix, such as Nitraria sibirica. Since both plants have similar adaptation characteristics, Nitraria is less detrimental compared to Tamarix.

\section{Material and Method}

\subsection{Study Area}

Datça - Bozburun Special Environmental Protection Area belongs to Muğla province. It was determined and announced by the Council of Ministers Decision No. 90/1117, dated 22.10.1990. Its population is 27,000 , and it exceeds 40,000 in summer. Its total area is $1444 \mathrm{~km} 2$ (Yalçın, 2017). The region's mean altitude is 200 meters, and Datça centrum coordinates are 36 $43^{\prime} 42^{\prime \prime}$ E, $27^{\circ} 39^{\prime} 07^{\prime \prime} \mathrm{N}$.

The Datça Peninsula is a great horst block between the Gökova Graben and the Hisarönü Graben. Datça-Bozburun Peninsulas generally consists of sloping, very stony, and degraded lands exposed to erosion. Approximately 95\% of the 47698 hectares of land available in Datça is rocky. The area that can be used efficiently for agriculture in the region does not exceed 10,000 hectares. The total forest area in the region is 110,359 hectares. In Figure 1, the surrounding red line indicates DatçaBozburun Special Environmental Protection Area.

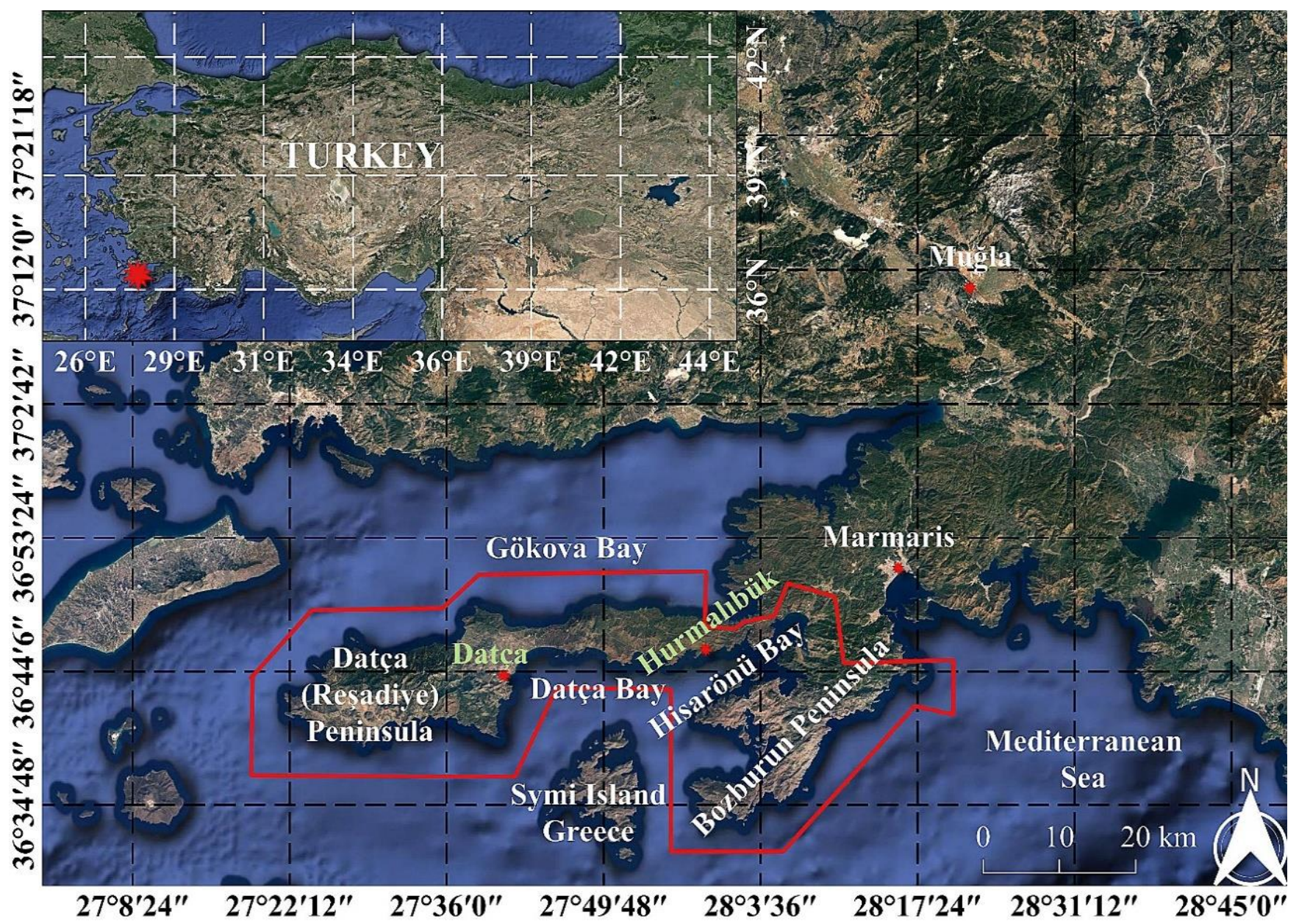

Figure 1. Datça-Bozburun Special Environmental Protection Area

Although it is known as a peninsula, Datça acts as an island due to the rock formations that do not allow fresh water to pass from the mainland. As a result of the tectonic movements in the Datça and Bozburun peninsulas, following the uplift and collapse (horst and graben), important streams and their branches were plunged into the land, the seawater tide and formed extraordinary beautiful bays and gulfs (Gökgöz \& Akdağoğlu, 2016). There are no large streams and rivers in the study area that show a regular flow in a topographic structure (Gül et al., 2017). In general, flow in stream beds is seen in rainy seasons and streams dry up entirely in the summer months.
About $60 \%$ of the lands have medium (6-12\%), steep (12$20 \%$, and very steep (20-30\%) slopes due to the very poor topography and the prevalence of mountains and hills. Due to severe erosion in $28 \%$ of the land and very severe erosion in $32 \%$ (Total 60\%), soils generally have shallow $(20 \mathrm{~cm}-50 \mathrm{~cm})$ and very shallow (less than $20 \mathrm{~cm}$ ) depths (Ustaoğlu et al., 2021).

Tamarix parviflora trees planted on the coast of Datça for landscape purposes have been preferred in the last few decades due to their tolerant metabolism to seawater (see Figure 2). Tamarix parviflora planted in the Datça Centrum coastal area gradually spread from the coast towards the inner regions. 

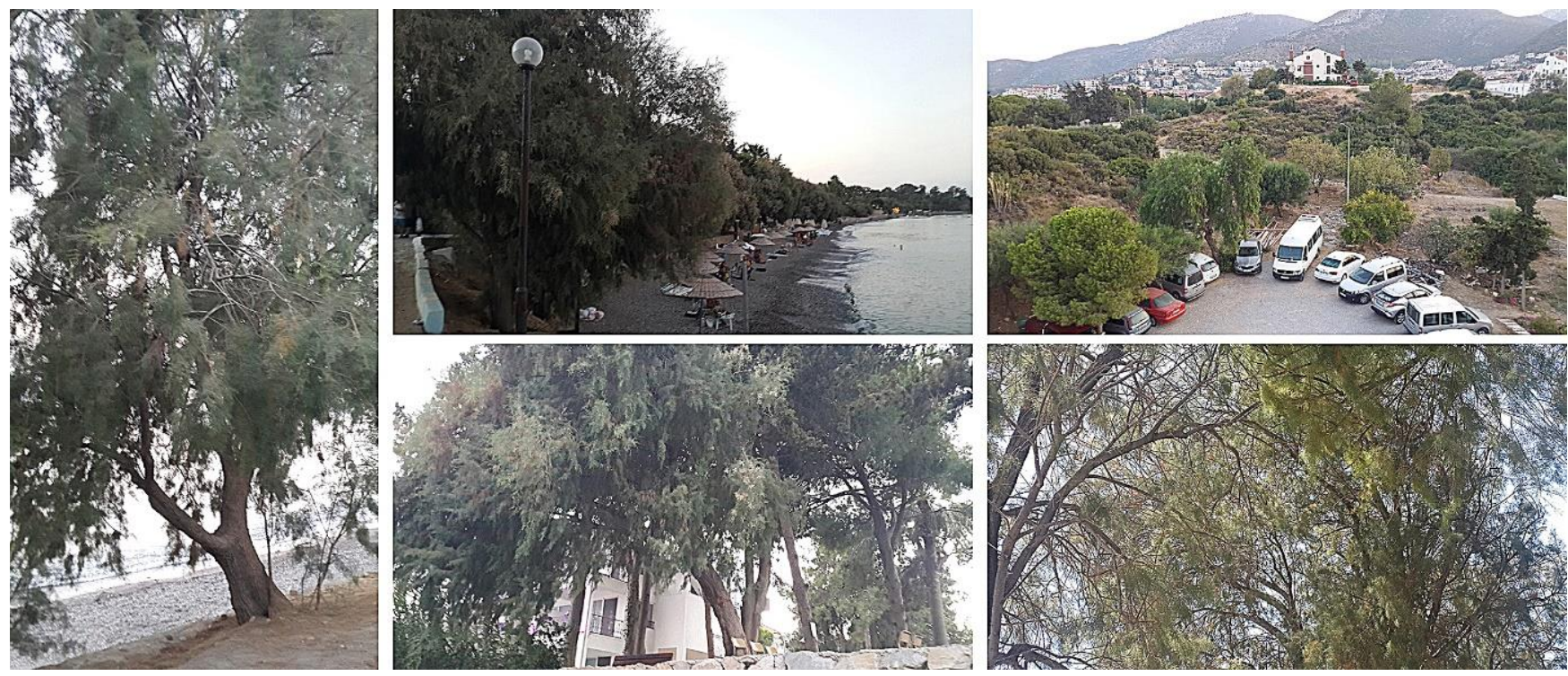

Figure 2. Tamarix parviflora trees planted in Datça Centrum

Pinus brutia, the most critical forest tree in the region, is incredibly close to the sea in dense communities in the lower parts. In some areas, it is rarely or not seen at all. Overgrown, high, or low bushes replace it.

Phoenix theophrasti (Datça date palm) is in the Hurmalıbük Bay $\left(36^{\circ} 45^{\prime} 42^{\prime \prime}\right.$ E, $\left.27^{\circ} 58^{\prime} 37^{\prime \prime} \mathrm{N}\right)$, in the Datça Peninsula. In the upper parts of the valley, palm trees disappear and leave their place in the Pinus brutia (red pine) forest (Boydak, 1985; Bozyiğit, 2020; Vardareli et al., 2019). Phoenix theophrasti is a beautiful and decorative-looking candidate to be a distinguished local type of park and garden (García-Granero et al., 2020). It can be rejuvenated naturally in seed and vegetative ways (See Figure $3)$.
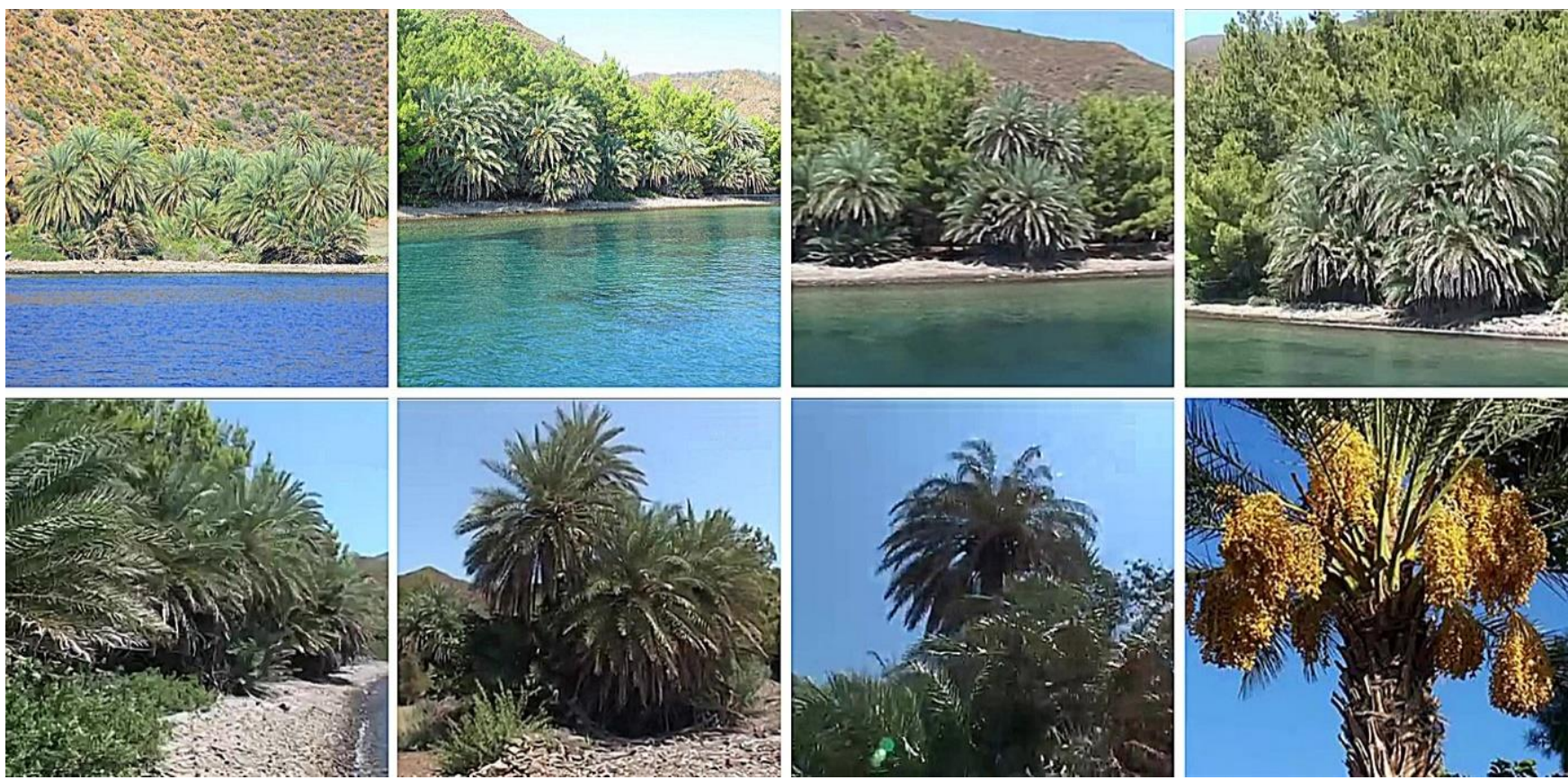

Figure 3. Phoenix theophrasti trees in Hurmalıbük, Pinus brutia trees in the rear

Datça and Bozburun Peninsulas are regions with limited agricultural potential due to their natural and physical structures. There is almost no garden and field agriculture, and the land is covered with almond and olive groves. Accordingly, agriculture is carried out in conditions without water. Almond is an essential source of livelihood in the region's economy, primarily due to the sales income. In addition to agriculture, the rural population earns its livelihood by beekeeping, fishing, working in the forest, or collecting herbal products such as laurel, thyme, and carob. The economy of the peninsulas is based on the service sector. Tourism is the driving sector that develops other sectors in the region. These are trade, transport, construction, small industry sectors, and public services.

Datça is an arid region, and annual evaporation is higher than yearly rainfall. The annual average rainfall is $685 \mathrm{~mm}$, potential 
evaporation and transpiration are $950 \mathrm{~mm}$. The situation is getting worse due to climate change (DSİ, 2017).

There are no rivers that can provide water to Datça. Spring waters are not suitable for wide-scale use. The only source is underground water storage. The largest aquifer in the Datça Peninsula is in Karaköy - Reşadiye - Kızlan region, which is called the Datça graben (crestal collapse graben). The geological structure of the peninsula does not allow groundwater to be fed from the mainland. In the Datça Plain water basin, the water budget depends on sources such as rainfall 15.0 million $\mathrm{m}^{3}$ / year, and this value is 20 percent of the total annual rain retained through infiltration by the soil. Discharge from wells and springs is 9.2 million $\mathrm{m}^{3}$ / year (discharge from springs 4.1 million $\mathrm{m} 3$ / year, discharge from wells 5.1 million $\mathrm{m}^{3} /$ year), discharge from underground to the sea is 5.8 million $\mathrm{m}^{3} /$ year, Datça Basin operating reserve is 10.8 million $\mathrm{m}^{3} /$ year (DSI, 2000). State Hydraulic Works (DSI) clearly states that aquifers' safety level is about to be exceeded. The safe water supply is in danger of running out (DSI, 2017). 1999 consumption was 50 percent of the reserve, and the population has increased by nearly 50 percent since then. Agricultural production, including autumn tomato, has also increased significantly in the last 22 years. In this case, we can estimate that we have exceeded the 1999 consumption values by more than 50 percent. In other words, Datça has started to consume more than 2.7 million cubic meters of the additional annual reserve (Muski, 2017). All wells drain the same aquifer, and the aquifer is alarming. Hence, due to aquifer water use, the groundwater level is continually being lowered, and Datça observes the adverse effects of this situation. The wild olives, thyme, and puree in the highlands are drying up. The wells are drying and need to dig pumps deeper. Salinization has begun in the coastal wells. Wild-olive (Olea oleaster), Garden thyme (Thymus vulgaris), Tree Heath (Erica Arborea) are drying in high elevations. The almond tree (Prunus dulcis), on the other hand, faces low yield in the short term and the danger of drying in the future. If the increase of Tamarix Tree population is not limited, the existing water can not supply demanded water without the high-cost projects to find alternative resources.

As an example for the alternative source, the Hisarönü Dam project was planned in 2016 (Republic of Turkey Governorship of Muğla, 2017). Projected dam called Hisarönü Dam in the northeast, Bördübet Bay $\left(36^{\circ} 47^{\prime} 39^{\prime \prime} \mathrm{E}, 28^{\circ} 0^{\prime} 55^{\prime \prime} \mathrm{N}\right)$, where the Sığla tree (Liquidambar Orientalis) and Ottoman Tombs, was decided to be built in 2016 to provide drinking water to Datça. Groundworks were carried out in the region. On the other hand, construction is frequently interrupted due to non-governmental organizations (NGO) representatives and villagers. Currently, studies continue at the planned stage. Transmission lines have been completed in more than five years. The dam project is not entirely under construction, and it is not expected to be finished soon.

High costs are subjected both financially and environmentally to seawater purification. Technology is not yet fully matured, and it is costly. Unfortunately, there are no alternative resources in the short/medium term, and the aquifer will continue to drain, and nature will continue to die.

\subsection{Biological and Mechanical Control of Tamarix}

Tamarix trees compete with natural plant species such as Creeping Buttercup (Ranunculus repens), Shepherd's wand. (Polygonum aviculare), Hogweed (Heracleum sphondylium) and Common Glasswort (Salicornia europaea) in the areas they occupy because they increase the soil surface salt content with their leaves' fall, create a cover by preventing sunlight, and consume excessive water with their long roots, preventing their chances of survival. For these reasons, they cause a decrease in the variety of natural species in the region they invaded. The research states that the Tamarix trees proliferate in the soil contaminated with heavy copper, iron, manganese, zinc, and other metals. For these reasons, animals' grazing should not be allowed in environments where Tamarix trees are present. It is known that algae and waste that cover the sea surface, especially in the summer months, cause flies and stench by accumulating on Tamarix tree roots. It also causes unwanted pollution and odors since they hold the wastes such as garbage and algae that come with the warm winds and currents and the putrefaction on the bottom soil.

The studies suggest biological control using the Tamarisk Beetle (Diorhabda elongate) as a considerable approach to manage Tamarix. The Tamarix beetle's release and monitoring indicate that the leaf beetle only feeds on salt cedar and has no impact on native vegetation. Succession methods by using competitive species to manipulate the environment around Tamarix are also advocated for (McAlpine et al., 2021). Alternatively, another way includes mechanical control that can be achieved through cutting or root plowing of the salt cedar roots. Also, burning the mowed and plowed debris is essential to prevent the resprouting of adventitious buds. The findings also indicate alternatives such as Nitraria to a similar environmental condition (Woutersen et al., 2018).

Figure 4 summarizes the research methodology in a chart clarifying the results of the processes including the biological and mechanical control of Tamarix. 


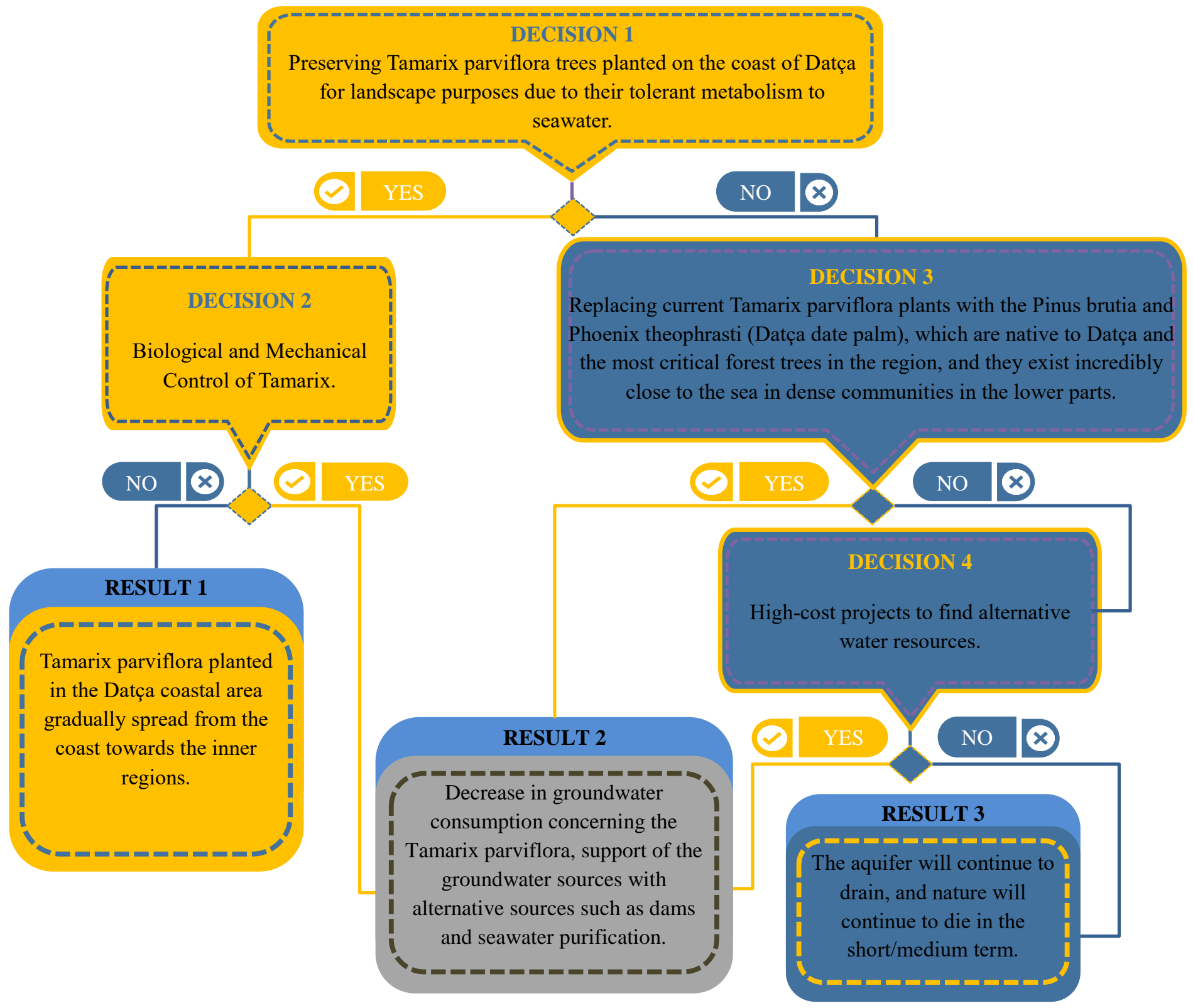

Figure 4. Summary of the research methodology

\section{Results}

According to these research findings, it was evident that Tamarix has adversely impacted the environment, especially the surroundings where it is dominant. With multiple pieces of literature focusing on the specific negative implications linked with Tamarix, the study compared and explored each view described by these studies. Among the significant findings tackled by various studies are the inhospitality of riparian areas and the overall displacement of native plants and wildlife.

The research found out that coastal dunes are also adversely affected by Tamarix through their natural and anthropogenic disturbances. More so, it was established that Tamarix impacts wildlife in terms of food accessibility and the growth of native vegetation. Water scarcity, in the long run, is also a big detrimental that affects the overall environment. Additionally, the lack of hospitality in the riparian regions causes significant changes in the ecosystem. Beyond that, Tamarix has established that Tamarix results in increased wild hazards like fires that further worsen habitats for native ecosystems.

e-ISSN: 2148-2683
Further, the results indicate that biological control through the Tamarix beetle Diorhabda spp is a quantifiable method to control the plant's spread and damaging effects (Richards et al., 2021); El Waer et al., 2018); Mc Kay et al., 2018). Results indicate that biological control may include successional trends using plants like box elder plants (McAlpine et al., 2021). More so, research highlights that succession plants like box elder are linked to a high mortality rate among Tamarix species. At the same time, considering alternative plants to replace Tamarix is quite a consideration.

Although little research has majored in possible plants to replace Tamarix, Woutersen et al. (2018) suggest that Nitraria (Nitraria sibirica) is an alternative halophyte. Natraria is well adapted to saline environments and has a comparably high growth rate as Tamarix.

Glenn et al. (1998) state that 500 grams of water for every gram of water accumulated in Tamarix biomass is transpired, leading to extreme water consumption compared to the other species. Considering the water budget, removing the Tamarix 
leads to storing more water in the subsurface (Gatewood et al., 1950; van Hylckama, 1974).

On the other hand, removing the vegetation reduces the soil's shading and causes evaporation greater than the transpiration from removed vegetation (Goodrich et al., 2000; Gazal et al., 2006). Replacing the deep-rooted plants with the shallow-rooted plants can be a solution where the water table is deeper (Wilcox et al., 2006). Replacement of the Tamarix with the native ground cover is the ultimate solution to decreasing groundwater loss (Nagler et al., 2005). Phoenix theophrasti and Pinus brutia are native to the region, and within this research, these two tree species were recommended to compose mixed vegetation. It is necessary to turn to alternative tree species in greening along the coast to prevent the Tamarix tree's damages. Phoenix theophrasti and Pinus brutia can be planted as an alternative to the Tamarix tree. Phoenix theophrasti trees are resistant to cold weather and moderate salt (Al Kharusi et al., 2017; Al-Khayri et al., 2018; Al Quariny et al., 2020). Tamarix has a high-water consumption rate of more than 750 liters per day (Owens \& Moore, 2007). Days palm tree (Phoenix theophrasti) 150 - 210 L per day (El-Juhany, 2010; Hazzouri et al., 2020). Pinus brutia water consumption is
27 liters per day (Özçelik, 2018). It was highlighted that how the plant community composition change affects the result (see Figure 5).

Figure 5 shows that reducing the percentage of area covered by the Tamarix parviflora tree would significantly improve groundwater resources' future conservation. For example, if the area covered by Tamarix parviflora alone is shared equally with Pinus brutia and Phoenix theophrasti, fifty-six percent; seventytwo percent in the case of leaving the entire site to the Phoenix theophrasti tree; If existing Tamarix parviflora trees are replaced with Pinus brutia, water conservation of up to ninety-six percent is envisaged. Phoenix theophrasti, with its aesthetic appearance, resistance to seasonal temperature difference, and saltwater tolerance, would be appropriate for the coastal areas. Pinus brutia should be preferably planted instead of Tamarix parviflora trees in the inner regions, as it consumes very little water. Table 1 shows the comparison of Tamarix parviflora, Pinus brutia, and Phoenix theophrasti in terms of water scarcity, species displacement, fire hazards, inhospitality of riparian areas, and altered soil systems to understand their favor in the Datça peninsula.

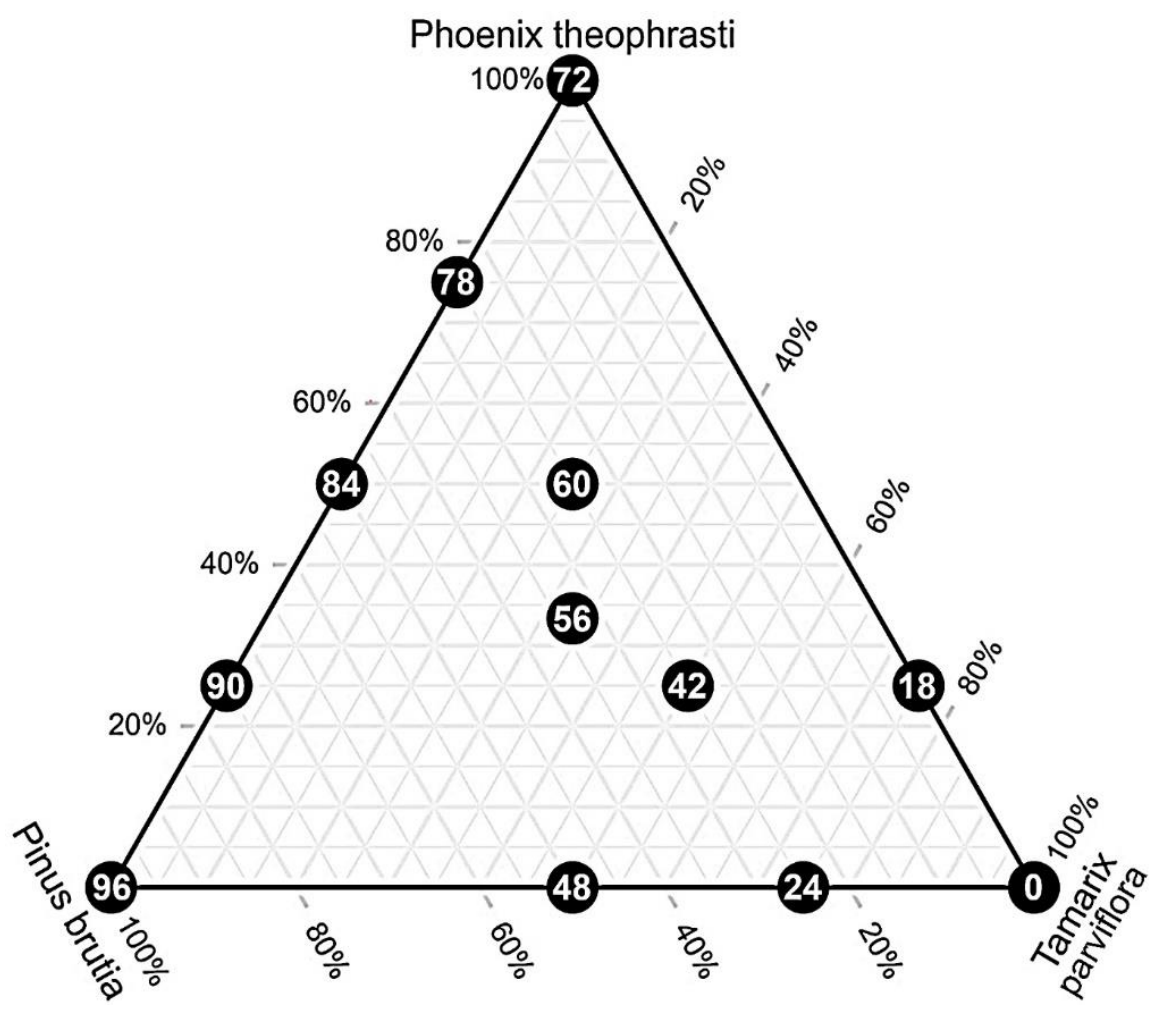

Figure 5. Percent reduction in groundwater consumption concerning the composition of plants in different percentages

Table 1. Ranks of Tamarix parviflora, Pinus brutia, and Phoenix theophrasti in terms of water scarcity, species displacement, fire hazards, inhospitality of riparian areas, and altered soil systems (1 - High, 2 - Moderate, and 3 - Low)

\begin{tabular}{l|c|c|c|c|c}
\hline Plant type & Water scarcity & $\begin{array}{c}\text { Species } \\
\text { displacement }\end{array}$ & Fire hazards & $\begin{array}{c}\text { Inhospitality of } \\
\text { riparian areas }\end{array}$ & Altered soil systems \\
\hline $\begin{array}{l}\text { Tamarix } \\
\text { parviflora }\end{array}$ & $\begin{array}{c}\text { 1 (Glenn et al., } \\
\text { 1998) }\end{array}$ & 1 (Marlin et al., 2017) & 2 (Richards et al., 2021) & 1 (Raynor et al., 2017) & 1 (Los Huertos, \\
Pinus brutia & 3 (Özçelik, 2018) & 2 (Quézel et al, 1990) & $\begin{array}{c}\text { 1 (Dimitrakopoulos \& } \\
\text { Papaioannou, 2001) }\end{array}$ & $\begin{array}{c}\text { 3 (Holmquist et al, } \\
\text { 2011) }\end{array}$ & 2(Li et al., 2020) \\
\hline $\begin{array}{l}\text { Phoenix } \\
\text { theophrasti }\end{array}$ & $\begin{array}{c}\text { 2 (Hazzouri et al., } \\
\text { 2020) }\end{array}$ & $\begin{array}{c}\text { 3 (Alston \& } \\
\text { Richardson, 2016) }\end{array}$ & $\begin{array}{c}\text { 3 (Dimitrakopoulos \& } \\
\text { Papaioannou, 2001) }\end{array}$ & $\begin{array}{c}\text { 2 (Holmquist et al., } \\
\text { 2011) }\end{array}$ & 3 (Chediack, 1999) \\
\hline
\end{tabular}




\section{Discussion}

Basing on the research findings, it is evident that Tamarix has over-extending adversities on the environment that have transpired since its introduction decades ago. The initial intent of using the plant for landscaping and recreation has become destructive in powerful ways unmeasurable. In this light, the plant is more associated with negativities than the initially imagined solution to flooding and overstretching river banks. Tamarix plant's commonly attributable consequences on the environment are; the inhospitality of riparian areas and displacement of native plants, poor adaptability of coastal dunes, negative impact on wildlife, long-term scarcity of water, increased wild hazards like fires, flooding, and control, respectively.

Tamarix spp is naturally adapted to salinity and excretes salts to the surrounding soils that cause a general change in the soil chemistry and structure due to the increased salinity. Consequently, this makes growth and development for the native vegetation difficult (Marlin et al., 2017). In this case, the riparian regions are rendered incompatible with the expected growth of native species. In this case, such species become extinct while others are completely displaced from their natural ecosystems. Therefore, this totals to declined diversity of species in the riparian regions due to the unfit environment.

Tamarix spp are classified as invasive species with extensional characteristics that render them dangerous to dunes. Irrespective of how vital the dunes ecosystems are, the dominance of Tamarix results in their reduced capacity to withstand harsh environmental impacts (Gallego-Fernández et al., 2021). Consequently, there are also reduced ecosystems due to the reduced vegetation that supports the survival of dunes.

The general characteristic that renders Tamarix undesirable is its salt and deep roots that negatively impact the surroundings. Tamarix secretes salt through its leaves and stem and releases them to the surrounding. The salty nature reduces the amount of protein found in the plant, hence disadvantaging animals. Simultaneously, salt released to the soil raises its salinity, making it not potential to support the growth of native vegetation.

The saline nature and presence of deep roots increase the water accessibility and uptake of Tamarix. The plant reproduces in high densities, which also increases the surface area for water uptake. At the same time, Tamarix is linked with reduced water tables and water loss in semiarid regions due to the same. On a similar note, Tamarix spp has a high evapotranspiration rate, which increases the amount of water excreted through the leaves and deposited to the surrounding (Yu et al., 2017).

Notably, Tamarix is well adapted to fire cases and can potentially sprout and grow in such hazardous regions. More so, the dense woods and roots of Tamarix spp create large amounts of decaying and live woody materials that attract more fire hazards. In this case, more habitats are destroyed while multiple ecosystems are displaced and altered (Richards et al., 2021).

Tamarix forms an incredible stance that causes extreme troubles concerning flooding. The roots damage pipe systems, invade and plug up the sewerage pipes and the water supply system, and even damage the buildings' concrete foundations. Invasive root spread causes a risk of clogging the underground channels and having an unforeseen flooding event.
After they burn, they come back stronger, tend to self fertilizer, and come back much more robust and denser.

Since the negativities of Tamarix were noted, a century after its introduction, the US Department of Agriculture (USDA) has developed several approaches to counter the acute effects of Tamarix. Methods such as the elimination of Tamarix biologically through an insect called Tamarisk Beetle (Diorhabda spp) are utilized (Chen et al., 2019). Additionally, other reliable methods include mechanical control like cutting the roots or using chemicals to reduce sprouting instances.

The only way to kill the Tamarix tree is to get the roots out. It is necessary to remove the roots according to an effective treatment and management program, but that's not where it stops because these trees produce seeds ten months out of the year. There's always an active seed back, and it just takes a little bit of moisture to get it planted. Through the herbicide treatments or manually pulling, the little Tamarix starts to keep it from growing back.

All of this demonstrates how expensive the Tamarix plant has become over time. Sharma et al. (2005) evaluated the economic impact of the invasive species Tamarix and predicted a value loss of $\$ 7$ to $\$ 16$ billion in ecosystems in the Western United States over 55 years.

Besides, it was revealed that, in replacing Tamarix trees with Phoenix theophrasti and Pinus brutia trees that are native to Datça in specific percentages, the groundwater consumed by the trees for metabolic water use could decrease high rate.

\section{Conclusions and Recommendations}

Currently, some alien species' environmental impact exists to be problematic irrespective of the control methods applied. The general change in the environment, alongside the Tamarix plant's negative implications, has raised too many concerns. Notably, Tamarix spp, also called salt cedar, was initially introduced in the US as an ornament and plant for landscaping along the coastal beaches. However, as time passed, the plant replaced the initially present native vegetation. Over time, the adversities of Tamarix worsened and took a toll on the environment. Remarkably, the riparian regions are no longer hospitable to the initial native vegetation due to the increased salinity. Hence, before the soil loses its fertility, the Tamarix parviflora trees have to be replaced by the native vegetation of Datça.

Further, issues of water scarcity were rampant and still are due to the reduced water tables. Additionally, both wildlife and native products were either extinct or displaced. Notably, such methods have been implemented to reduce the existing extremities. These methods' effectiveness is still in question, which renders the need for more research. More research is essential to establish solutions for the specific challenges posited by each impact.

In Datça, the plants and trees in higher elevations dry up because they cannot access sufficient water. The water in the wells near the sea is getting salty. It is necessary to use groundwater economically and consciously to avoid water shortage problems shortly. Unfortunately, it was impossible to establish this awareness in Datça, a summer resort. It is crucial to carry out infrastructure works that will provide water to aquifers during rainfall. To prevent water leakages and save water in homes, highbudget infrastructure works are an economic burden, so it is not 
easy to implement soon. While Datça is currently suffering from a lack of water, it can not afford the future groundwater use by Tamarix trees, which gradually move from the beaches to the inner regions. This possibility should be avoided without delay.

\section{References}

Al Kharusi, L., Assaha, D. V., Al-Yahyai, R., \& Yaish, M. W. (2017). Screening of date palm (Phoenix dactylifera L.) cultivars for salinity tolerance. Forests, 8(4), 136.

Al-Khayri, J. M., Naik, P. M., Jain, S. M., \& Johnson, D. V. (2018). Advances in date palm (Phoenix dactylifera L.) breeding. In Advances in plant breeding strategies: fruits (pp. 727-771). Springer, Cham.

Al-Qurainy, F., Khan, S., Tarroum, M., Nadeem, M., Alansi, S., Alshameri, A., \& Gaafar, A. R. (2020). Comparison of salt tolerance between two potential cultivars of Phoenix dactylifera L. growing in Saudi Arabia. Pak. J. Bot, 52(3), 753-761.

Alston, K. P., \& Richardson, D. M. (2006). The roles of habitat features, disturbance, and distance from putative source populations in structuring alien plant invasions at the urban/wildland interface on the Cape Peninsula, South Africa. Biological Conservation, 132(2), 183-198.

Boydak, M. (1985). The distribution of Phoenix theophrasti in the Datça Peninsula, Turkey. Biological Conservation, 32(2), 129-135.

Bozyiğit, R. (2020). Seydikemer İlçesi (Muğla) Topraklarının Özellikleri ve Kullanımı Üzerine Bir Değerlendirme. Avrupa Bilim ve Teknoloji Dergisi, (18), 695-706.

Chediack, S. E. (1999). The small palm (Allagoptera campestris) in Misiones, Argentina. Palms-Lawrence, 43, 166-169.

Chen, H., Yang, C., Ren, A., Guo, K., Feng, X., Li, J., ... \& Wang, J. (2019). The Evapotranspiration of Tamarix and Its Response to Environmental Factors in Coastal Saline Land of China. Water, 11(11), 2273. https://doi.org/10.3390/w11112273

Chew, M. K. (2009). The monstering of Tamarix: How scientists made a plant into a problem. J. Hist Biol, 42, 231-266.

Dimitrakopoulos, A. P., \& Papaioannou, K. K. (2001). Flammability assessment of Mediterranean forest fuels. Fire Technology, 37(2), 143-152.

DSİ (2000). Datça - Bozburun Environmental Plan Research Report, Ankara.

DSİ, (2017), DSI General Directorate 2016 Annual Activity Report, Ankara.

El Waer, H. N., Henry, A., Merewether, K., \& Sher, A. A. (2018). Invasion and restoration of western rivers dominated by Tamarix spp [Chapter 4]. In: Johnson, R. Roy; Carothers, Steven W.; Finch, Deborah M.; Kingsley, Kenneth J.; Stanley, John T., tech. Eds. 2018. Riparian research and management: Past, present, future: Volume 1. Gen. Tech. Rep. RMRS-GTR377. Fort Collins, CO: US Department of Agriculture, Forest Service, Rocky Mountain Research Station (p. 47-61). DOI: http://doi. Org/10.2737/RMRS-GTR-377-CHAP4., 377, 4761.

El-Juhany, L. I. (2010). Degradation of date palm trees and date production in Arab countries: causes and potential rehabilitation. Australian Journal of Basic and Applied Sciences, 4(8), 3998-4010.

Erfanifard, Y., \& Khosravi, E. (2019). Saltcedar (Tamarix mascatensis) inhibits the growth and spatial distribution of eshnan (Seidlitzia rosmarinus) by enrichment of soil salinity in a semiarid desert. Plant and Soil, 440(1), 219-231. DOI: 10.1007/s11104-019-04064-3.

Feagin, R. A., Furman, M., Salgado, K., Martinez, M. L., Innocenti, R. A., Eubanks, K., Figlus J., Huff, T. P., Sigren, J. \& Silva, R. (2019). The role of beach and sand dune vegetation in mediating wave run up erosion. Estuarine, Coastal and Shelf Science, 219, 97-106.

Gallego-Fernández, J. B., Martínez, M. L., García-Franco, J. G., \& Zunzunegui, M. (2021). Multiple seed dispersal modes of an invasive plant species on coastal dunes. Biological Invasions, 23(1), 111-127.

García-Granero, J. J., Skoula, M., Sarpaki, A., Cárdenas, M., Madella, M., \& Bogaard, A. (2020). A long-term assessment of the use of Phoenix theophrasti Greuter (Cretan date palm): The ethnobotany and archaeobotany of a neglected palm. Journal of Ethnobiology, 40(1), 101-114.

Gatewood. J. S., Robinson, T. W., Colby, B. R., Helm. J. D., \& Halpenny, L. C., (1950). Use of water by bottom-land vegetation in lower Safford Valley, Arizona (210 p.). US Geological Survey Water-Supply Paper 1103.

Gazal, R. M., Scott, R. L., Goodrich, D. C., and Williams, D. G., (2006). Controls on transpiration in desert riparian cottonwood forest. Agricultural and Forest Meteorology, 137(1-2), 56-67.

Glenn. E., Tanner, R., Mendez, S., Kehret, T, Moore, D., Garcia, J., \& Valdes. C., (1998). Growth rates, salt tolerance and water use characteristics of native and invasive riparian plants from the Colorado River delta. Mexico. Journal of Arid Environments, 40(3), 261-294.

Gökgöz, A., \& Akdağoğlu, H. (2016). Hydrogeology and hydrogeochemistry of a coastal low-temperature geothermal field: a case study from the Datça Peninsula (SW Turkey). Environmental Earth Sciences, 75(15), 1-18.

González, E., Sher, A. A., Anderson, R. M., Bay, R. F., Bean, D. W., Bissonnete, G. J., ... \& Shafroth, P. B. (2017). Vegetation response to invasive Tamarix control in southwestern US rivers: a collaborative study including 416 sites. Ecological Applications, 27(6), 1789-1804. https://digitalcommons.unl.edu/usgsstaffpub

Goodrich, D. C., Scott, R., Qi, J., Goff, B., Unkrich, C. L., Moran, M. S., Williams, D., Schaeffer, S., Snyder, K., MacNish, R., Maddock, T, Pool, D., Chehbouni, A., Cooper, D. I., Eichinger, W. E., Shuttleworth, W. J., Kerr, Y., Marsett, R.. \& Ni, W., (2000). Seasonal estimates of riparian evapotranspiration using remote and in-situ measurements. Agricultural and Forest Meteorology, 105(1-3), 281-309.

Gül, M., Danladi, I. B., \& Kore, B. M. (2017). Coastal types of graben: the Gulf of Gökova, Mugla-SW Turkey. Journal of Coastal Conservation, 21(1), 127-138.

Hazzouri, K. M., Flowers, J. M., Nelson, D., Lemansour, A., Masmoudi, K., \& Amiri, K. (2020). Prospects for the study and improvement of abiotic stress tolerance in date palms in the post-genomics era. Frontiers in plant science, 11, 293.

Holmquist, J. G., Schmidt-Gengenbach, J., \& Slaton, M. R. (2011). Influence of invasive palms on terrestrial arthropod assemblages in desert spring habitat. Biological Conservation, 144(1), 518-525.

Horoshevsky, N. (2020). Is Tamarix Evergreen? Find answer. https:/findanyanswer.com/is-tamarix-evergreen

Katz, O., \& Stavi, I. (2020). Hierarchical effects of Tamarix aphylla afforestation in a sand dune environment on vegetation structure and plant diversity. Forest Science, 66(5), 568-577. https://doi.org/10.1093/forsci/fxaa011 
Li, S., Huang, X., Lang, X., Xu, F., Li, H., Zheng, M., \& Su, J. (2020). Effect of selective logging on soil microbial communities in a Pinus yunnanensis forest. Land Degradation \& Development, 31(16), 2268-2280.

Liu, J., Rong, Q., \& Zhao, Y. (2017). Variations in soil nutrients and salinity caused by tamarisk in the coastal wetland of the Laizhou Bay, China. Ecosphere, 8(2), e01672. https://doi.org/10.1002/ecs2.1672

Los Huertos, M. (2020). Archeology of Inland Waters. Ecology and Management of Inland Waters, 27. DOI: 10.1016/B9780-12-814266-0.00014-3

Marlin, D., Newete, S. W., Mayonde, S. G., Smit, E. R., \& Byrne, M. J. (2017). Invasive Tamarix (Tamaricaceae) in South Africa: current research and the potential for biological control. Biological invasions, 19(10), 2971-2992. DOI: 10.1007/s10530-017-1501-6

Mc Kay, F., Logarzo, G., Natale, E., Sosa, A., Walsh, G. C., Pratt, P. D., \& Sodergren, C. (2018). Feasibility assessment for the classical biological control of Tamarix in Argentina. BioControl, 63(2), 169-184. https://doi.org/10.1007/s10526017-9855-3

McAlpine, K. G., Lamoureaux, S. L., \& Timmins, S. M. (2021). Understory vegetation provides clues to succession in woody weed stands. New Zealand Journal of Ecology, 45(1), 3418. https://www.researchgate.net/profile/Kate-

Mcalpine/publication/344324539_Understory_vegetation_pr ovides_clues_to_succession_in_woody_weed_stands/links $/ 5$ f67de $0 \overline{\mathrm{e}} 4585 \overline{1}$ 5 $\overline{\mathrm{b}} 7 \mathrm{cf} 447203 /$ Understory-vegetationprovides-clues-to-succession-in-woody-weed-stands.pdf.

MUSKI, (2017). Mugla Water and General Directorate of Sewerage Administration, the municipal progress report for 2016, Muğla.

Nagler, P. L., Scott, R. L., Westenburg. C., Cleverly, J. R.. Glenn, E. P., \& Huete, A. R. (2005). Evapotranspiralion on Western US rivers estimated using the Enhanced Vegetation Index from MODIS and data from eddy covariance and Bowen ratio flux towers. Remote Sensing of Environment, 97(3), 337-351.

Noronha, N. (2020). Why is salt cedar bad? AskingLot. https://askinglot.com/why-is-salt-cedar-bad.

Owens, M. K., \& Moore, G. W. (2007). Saltcedar water use: realistic and unrealistic expectations. Rangeland Ecology \& Management, 60(5), 553-557.

Özçelik, M. S. (2018). Annual water consumption of an Anatolian black pine in a sub-humid region. Forestist, 68(2), 101-105.

Powell, A. (2005). Salt cedar management in New Mexico. Rangelands, 27(4), 18-20.

Quézel, P., Barbero, M., Bonin, G., \& Loisel, R. (1990). Recent plant invasions in the Circum-Mediterranean region. In Biological invasions in Europe and the Mediterranean Basin (pp. 51-60). Springer, Dordrecht.

Raynor, E. J., Cable, T. T., \& Sandercock, B. K. (2017). Effects of Tamarix removal on the community dynamics of riparian birds in a semiarid grassland. Restoration Ecology, 25(5), 778-787. DOI: $10.1111 /$ rec. 12497

Republic of Turkey Governorship of Muğla (2017). Muğla Provincial Environmental Status Report 2016. Muğla, Turkey.

Richards, R., Whitesides, R., Poulson, C., Palmer, M., Belliston, N., \& Hess, S. (2021). What is Tamarisk? Rivers Edge West. https://riversedgewest.org/what-tamarisk

Setshedi, K. T. A., \& Newete, S. W. (2020). The Impact of Exotic Tamarix Species on Riparian Plant Biodiversity. Agriculture, 10(9), 395.
Sharma, G. P., Singh, J. S., \& Raghubanshi, A. S. (2005). Plant invasions: emerging trends and future implications. Current science, 726-734.

Sher, A. A., El Waer, H., González, E., Anderson, R., Henry, A. L., Biedron, R., \& Yue, P. (2018). Native species recovery after reduction of an invasive tree by biological control with and without active removal. Ecological Engineering, 111, 167-175.

Šilc, U., Stešević, D., Rozman, A., Caković, D., \& Küzmič, F. (2019). Alien species and the impact on sand dunes along the NE Adriatic coast. In Impacts of invasive species on coastal environments (pp. 113-143). Springer, Cham. DOI: 10.1007/978-3-319-91382-7_4

Stešević, D., Luković, M., Caković, D., Ružić, N., Bubanja, N., \& Šilc, U. (2017). Distribution of alien species along sand dune plant communities' zonation. Periodicum biologorum, 119(4), 239-249.

The King James Bible (2020). Genesis 21-33. King James Bible Online. https://www.kingjamesbibleonline.org/Genesis-2133/

Uhey, D. A., Rowe, A. K., \& Kendall, D. (2020). Tamarisk Alters Arthropod Composition, but has Little Negative Effect on Richness and Abundance in Southwestern Colorado. Southwestern Entomologist, 45(3), 585-600. https://doi.org/10.3958/059.045.0301

Ustaoğlu, B., Ikiel, C., Dutucu, A. A., \& Koç, D. E. (2021). Erosion Susceptibility Analysis in Datça and Bozburun Peninsulas, Turkey. Iran J Sci Technol Trans Sci, 45(2), 557570.

van Hylckama, T. E. (1974). Water use by saltcedar as measured by the water budget method (30 p.). US Geological Survey Professional Paper 491-E.

Vardareli, N., Doğaroğlu, T., Doğaç, E., Taşkın, V., \& Taşkın, B. G. (2019). Genetic characterization of tertiary relict endemic Phoenix theophrasti populations in Turkey and phylogenetic relations of the species with other palm species revealed by SSR markers. Plant Systematics and Evolution, 305(6), 415429.

Wilcox, B. P., Owens, M. K., Dugas, W. A.. Ueckert, D. N., \& Hart, C. R. (2006). Shrubs, streamflow, and the paradox of scale. Hydrological Processes, 20(15), 3245-3259.

Woutersen, A., Jardine, P. E., Bogotá-Angel, R. G., Zhang, H. X., Silvestro, D., Antonelli, A., ... \& Hoorn, C. (2018). A novel approach to study the morphology and chemistry of pollen in a phylogenetic context, applied to the halophytic taxon Nitraria L.(Nitrariaceae). Peer J, 6, e5055. DOI: 10.7717/peerj.5055.

Xia, J., Lang, Y., Zhao, Q., Liu, P., \& Su, L. (2021). Photosynthetic characteristics of Tamarix chinensis under different groundwater depths in freshwater habitats. Science of The Total Environment, 761, 143221.

Yalçın, G. (2017). Using of Remote Sensing/GIS Technology on Special Environmental Protection Areas in Turkey and Sustainable Land Management. In I. Koleva, U. D. Yuksel \& L. Benaabidate (Eds.), Ecology, Planning and Design (pp. 338-428). St. Kliment Ohridski University Press, Sofia, Bulgaria.

Yu, T., Qi, F., Si, J., Zhang, X., \& Zhao, C. (2017). Tamarix ramosissima stand evapotranspiration and its association with hydroclimatic factors in an arid region in northwest China. Journal of Arid Environments, 138(1), 18-26. DOI: 10.1016/j.jaridenv.2016.11.006 